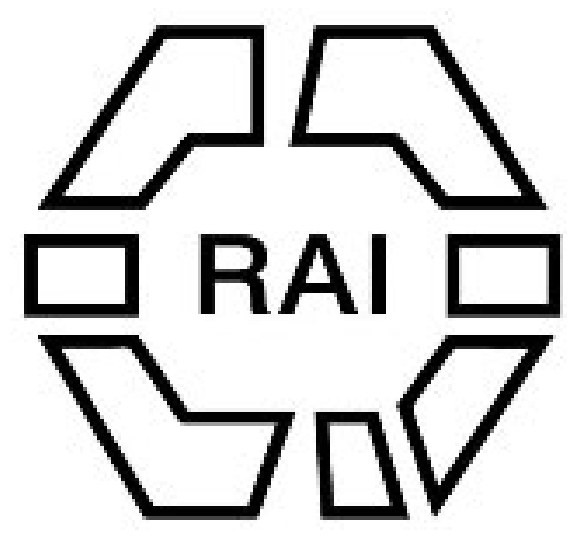

Negritoes in Borneo

Author(s): H. Ling Roth

Source: The Tournal of the Anthropological Institute of Great Britain and Ireland, Vol. 25 (1896), pp. 262-271

Published by: Royal Anthropological Institute of Great Britain and Ireland

Stable URL: http://www.jstor.org/stable/2842249

Accessed: 16/06/2014 17:30

Your use of the JSTOR archive indicates your acceptance of the Terms \& Conditions of Use, available at http://www.jstor.org/page/info/about/policies/terms.jsp

JSTOR is a not-for-profit service that helps scholars, researchers, and students discover, use, and build upon a wide range of content in a trusted digital archive. We use information technology and tools to increase productivity and facilitate new forms of scholarship. For more information about JSTOR, please contact support@jstor.org. 
consists of a knob and handle, and the game depends on the skill with which it is throwrs to a distance. An interesting description $^{1}$ of this game has also been given by Mr. W. E. Stanbridge, and is important, inasmuch as it differs in some particulars from the account given by Smyth.

I hope on a future occasion to forward to the Institute the native name of these tops, and the systematic name of the gourd of which they are made.

\section{Explanation of Photograph.}

Three tops from the Barron River, obtained by Mr. W. S. Day.

\section{Negritoes in Borneo. By H. Ling Roth.}

The question, "Are there any Negritoes in Borneo?" is one of great interest, and has been as yet by no means solved.

The interest in the question lies in the fact that while in the surrounding countries the existence of Negritoes has been more or less proved, no European has yet met with a Negrito in Borneo. There are plenty of Negritoes in the Philippine Islands (A. B. Meyer, "Die Philippinen," II, Negritos ; Dresden, fol., 1893), and while Alex. Dalrymple says there are none in Palawan, Mr. A. Hart Everett says he could hear nothing of any Negritoes in that part of Palawan visited by him. They exist in the Malay Peninsula. In Sumatra the Kubus had been considered to have at some remote period intermingled with the Negritoes, whilo their osteology leans decidedly to the Malays. (Dr. Garson, J.A.I., xiv, 132.) In Java and Madura I cannot find that Negritoes are proved to have existed, although the Kalangs are very like them. In Sumbawa there is a race of people of whom almost nothing is known (F. H. H. Guillemard, "Australasia," II, 1894, p. 358), but it is not stated they might be Negritoes. "It is highly probable that a low and primitive race $^{2}$ did once inhabit Celebes, but if so, it has, so far as we know, completely disappeared" (ibid., p. 288).

It was for this reason-namely, widespread surrounding negritic population - that, when at the meeting of the British Association at Oxford in 1894, I pointed out we must suspend our judgment as to the existence of Negritoes in Borneo, I was told probabilities were against me, as Borneo was in the midst

1 “Trans. Ethnol. Soc., 1861," p. 297.

2 Not necessarily negritic - nor is this inferred by Dr. Guillemard.-H. L. R. 
of a negritic centre. Since then, I find that Dr. A. B. Meyer ${ }^{1}$ had come to the same conclusion as I did, arguing from a somewhat different standpoint to that which I took up. He has gone so thoroughly into the matter, that I translate his statement.

"Although for a long time past all authors were of the opinion that the reports of the existence of Negritoes in Borneo were not to be trusted, their existence has lately been repeatedly asserted. Pickering ('U.S. Explor. Exp.,' 1848, ix, 174) notices especially their absence, and Waitz-Gerland ('Anthr.,' 1865, v 47) express themselves as follows: 'Older reports have mentioned Papuans which were said to have been found in the interior of Borneo, but W. Earl ${ }^{2}$ remarks very correctly ("East Seas," 1836, 256) that no traveller has himself seen them, Kessel ${ }^{3}$ also only heard Malay traders speak of them (“Z. f. a. Erdk. N. F.,' iii, 379) and Marsden (“Misc.,' 37) only mentions that a small Borneo chief spoke of woolly-haired Tammans in the interior; on the other hand, Schwaner ("Borneo," 1853, i, 64) assures us particularly that with the exception of the Papuans $s^{4}$ introduced into the north-east of the country, there are no others. Later on Earl ("Races Ind. Arch." $1853,146)$ found the existence of Papuans in the interior of Borneo somewhat more probable but still without sufficient foundation in fact.' Earl's account in question is held to be credible by others, but it is practically a matter of individual opinion whether one believes it or not. It mentions that a ship's captain stranded in 1844 on the north coast of Borneo, at the Berau or Kuran rivers, once met, fifty miles inland, at the foot of Mount Tabur, 17 curly headed small men ornamented with cicatrices, at least so the man himself told him (Earl), and his evidence must be considered satisfactory. Everything else which Earl brings forward is calculated to weaken rather than to strengthen the case. The district in question has certainly not often been travelled over, but now that north Borneo has been traversed several times, and even Mount

1 A. B. Meyer, “Die Philippinem," ii, Negritos. Dresden, fol., 1893, pp. 71-2.

2 Earl only says that no Dyak whom he met had seen them, notwithstanding that the natives assert their existence; but as they also assert the existence of tailed people, they must not be believed.-A. B. M.

3 Kessel says that in the interior, "namely, in the north-east," they cultivate the soil. This statement is perfectly incredible.-A. B. M.

4 These are Papuans from New Guinea, whom the Sulus have brought home as slaves from their widespread piratical expeditions, or whom they have purchased elsewhere, as, for instance, in the Moluccas. Schwaner says, "the few Papuans which were met in the north-east of Borneo come from the fatherland of the Papuans, and have been carried off by the Sulu pirates." He adds also, "that the local traditions there speak against the existence of Negritoes."-A. B. M. 
Kinibaln has been several times ascended, and no traces of Negritoes ${ }^{1}$ have anywhere been found, one must very strongly doubt the credibility of the statement of a ship's captain. Junghuhn ("Battaländer," 1817, i, 220, note) considers it unimaginable that anyone could have overlooked such a specialised race with woolly hair and black skin in Borneo. Everett, who possesses a profound knowledge of north-west Borneo, leaves the reader in the dark as to whether he believes the statement of the captain or not, nevertheless he seems to be more on the side of the doubters ("Nature," 1880, xxi, 588). Giglioli ("Viaggio Magenta," 1875, 253) believes the statement, and adds: "Beccari found no trace of Negritoes in Borneo, "cioe vide indegeni coi capelli crespi." Unfortunately Giglioli says nothing more, and in the year $1876^{\circ}$ when he published his "Studi sulla razza negrita" ("Arch., p. Antr.," vi, 315), he said nothing new on the above remark of Beccari; it is therefore only a matter of casual observation upon which no value can be placed. I think this all the more, because when Zunnetti ("Arch. p. Antr.," 1872, ii, 159), discussing a Dyak skull of Beccari's collection, speaks against the existence of Negritoes in Borneo, he makes no mention of any contrary opinion of Beccari's. Finally, Hamy ("Bull. Soc. d'Anthr.," 1876, 116) refers to the above mentioned captain's statement, and describes a skull which Jourdan had received at the Lyons Museum as a Negrito skull from Borneo; he says (p. 118) that this skull fully proves the existence of Negritoes in the heart of Borneo. In 1882 Quatrefages and Hamy ("Cr. Ethn.," 195, figs. 212,213 ) published an illustration of this skull as such; it is, ornamented with incised lines such as we know the trophy skulls collected by the Dyaks of Borneo possess. I do not consider that in this case the conclusion drawn from certain anatomical characters on the race are justified. When, moreover, the Bishop of Labuan² informs us ("Tr. Ethn. Soc." N.S., 1863, ii, 25) that the traditions of the Dyaks of north-west Borneo indicate that a black race had preceded them, one must

1 See for example Whitehead ("Expl. Kina Balu," 1893); compare Latham ("Essays," 1860, 192). Treacher ("J. Str. Br. R. As. Soc.." 1890. No. 1, p. 101), says, "There are no Negritoes in Borneo." Hose ("Journ. Anthrop. Inst.," 1893, xxiii, p. 156) considers the Punans, "the nomadic tribes found at the head waters of all the big rivers in central Borneo," as the real aborigines (p. 157): "I have no doubt in my mind that this wandering race of people are the aboriginals of the country." The Punans are real Malays.-A. B. M.

2 The Bishop's (Dr. McDougall's) words are: "With respect to the races. of people, the present occupants were, he thought, the remains of a second ware of immigration. The black race or Papuas, he thought, came in first, and the second wave of Malay or Dyak race followed; the traditions of the country refer to such an event, and the people speak of a bluck race having been there before them. The present race were probably from Inåia." ("Trans. Ethno. Soc.," ii, 1863, p. 26).-H. L. R. 
not jump to the conclusion that they refer to Negritoes ; besides, according to Waitz-Gerland ("Anthr.," 1865, v, i, 47), the traditions read quite otherwise. On what Flower quite recently supports his short statement ("J.A.I.," 1889, xviii, 82), that Negritoes exist in the interior of Borneo I do not know for certain, but I presume it is on the map in Quatrefages' "Hist. Gen. des Races Hum." (1889, to p. 343), or to the latter's references in "Les Pygmées" (1887-42), but which, as we saw above, do not stand investigation. How carelessly Quatrefages went about this question I may show by a single example. He says (l.c., p. 76), "A Bornéo, les Dayaks chassent au Négrito comme à la bête fauve," and refers to Earl ("Papuans," 1853, 147); but Earl only reproduces an account of Dalton's on certain tribes of North Borneo, of whom Earl says that they may perhaps be related to the above named more than questionable Negritoes of the ship's captain, in spite of the fact that Dalton himself calls them wild Dyaks. As Dalton lived eleven months on the Koti river, no one has the right to re-christen his Dyaks Negritoes. That which Earl adds to Dalton's account makes it to appear as quite settled that these people possibly could have been Negritoes. Compare also Meinicke's excellent remarks on the absence of Negritoes in Borneo ("Beitr. Eth. As.," 1837, p. 8). After all this I conclude that there is no proof yet of the existence of Negritoes in Borneo; all the same, we can only then judge with the fullest confidence when the whole interior shall have been fully explored."

The following is Mr. Earl's statement in full :-

"The interior of this large island is occupied by tribes of the brown race, whose warlike habits, and skill in the use of missiles, will account for the disappearance of a less civilised race from the southern and western parts of the island. In the year 1834, when on a visit to the western coast of the island, I was informed by some of the more intelligent among the natives, that a wild, woolly-haired people existed in the interior; but the information was mixed up with so many incredible details respecting their habits, that I was led to consider the whole as fabulous; and the subject is treated in this light in the narrative of my voyages, which was published soon after my return to England in the following year. ${ }^{1}$

1 The various tribes are said to differ considerably from each other, an assertion I do not pretend to dispute, although my own experience would go to prove the contrary, since I saw individuals belonging to several distinct tribes, who, with the exception of a difference of dialect, might be recognised as the same people, those who lived entirely on the water being much darker than the rest. It is said by the Dyaks themselves, that some parts of the interior are inhabited by a woolly-haired people; but as they also assert that men with tails like monkeys, and living in trees, are also discoverable, the accuracy of their accounts may be doubted. I met with no Dyak who had seen either, but as a 
"During a second visit to the Archipelago, my attention was chiefly directed to the more eastern islands, where the field was comparatively new, and I had no opportunity of obtaining farther information respecting the interior of Borneo until when again on my return to England in 1845. One of my fellow passengers on that occasion was Captain Brownrigg, whose ship, the 'Premier,' of Belfast, had been wrecked on the east cost of Borneo during the previous year, vrhen the European portion of the crew found refuge with the Rajah Mudah of Gunung Thabor, a place about 50 miles up the Buru or Kuran River, whence they were removed after a residence of several months by a Dutch vessel of war, which had been sent from Macassar for the purpose. Captain. Brownrigg was so kind as to entertain me frequently with accounts of the people among whom he had been thrown, and who had not previously been visited by Europeans. They appeared to me to differ in no essential particular from the other coast tribes of Borneo, except in being rather more advanced, as was evident, indeed, from the hospitable reception he met with among them; but my attention having been aroused by a repeated mention of 'darkies' as furming part of the population, I was induced to make some inquiries, when I found that he alluded to an inland tribe that only occasionally visited Gunung Thabor, and who were a short, but stoutly built, people, perfectly black, and with hair so short and curly that the head appeared to be covered with little knobs. This perfectly agrees with the general appearance of the hair of the Papuans, who keep the head shorn; and I have not the slightest doubt that they were unmixed Papusins. He also described the skins of the breast and shoulders as displaying many raised scarifications, apparently imilar to those of some New Guinea tribes, but which do not appear to be common among the mountain Papuans. On one occasion, a party of seventeen men, chiefly young and middle aged, visited the settlement for the express purpose of seeing the Europeans. They appeared to live on very friendly terms with the people of Gunung Thabor, from whom they obtained supplies of axes and chopping knives, giving the produce of the forests in exchange.

"It should be mentioned that this was Captain Brownrigg's first visit to the Archipelago, and he could scarcely have been aware that any peculiar interest was connected with this information, so that his evidence must be considered satisfactory. I

woolly-haired people is to be found scattered over the interior of the Malay Peninsula, their existence in Borneo seems by no means improbable."- "The Eastern Seas," p. 255.-H. L. R 
have since searched the published accounts of visitors to the east coast of Borneo, but the only allusion I can find to a people who may be allied to the same race, is contained in the papers of Mr. Dalton, who resided for eleven months on the Coti River, to the south of the Buru, during the years 1827-28. Mr. Dalton's papers were originally published in the 'Singapore Chronicle' of 1831: and the following extract is from Mr. Moor's 'Notices of the Indian Archipelago,' in which they are reprinted:-

" "Farther towards the north of Borneo are to be found men living absolutely in a state of nature, who neither cultivate the ground nor live in huts; who neither eat rice nor salt, and who do not associate with each other, but rove about some woods like wild beasts. The sexes meet in the jungle, or the man carries away a woman from some kampong. When the children are old enough to shift for themselves they usually separate, neither one afterwards thinking of the other; at night they sleep under some large tree, the branches of which hang low. On these they fasten the children in a kind of swing; around the tree they make a fire to keep off the wild beasts and snakes; they cover themselves with a piece of bark, and in this also they wrap their children; it is soft and warm, but will not keep out the rain. These poor creatures are looked on and treated by the Dyaks as wild beasts ; hunting parties of twenty-five and thirty go out and amuse themselves with shooting at the children in the trees with sumpits, the same as monkeys, from which they are not easily distinguished. The men taken in these excursions are invariably killed, the women commonly spared if young. It is somewhat remarkable that the children of these wild Dyaks cannot be sufficiently tamed to be entrusted with their liberty. Selgie (the Dyak chief of Coti) told me he never recollected an instance when they did not escape to the jungle the very first opportunity, notwithstanding, many of them had been kindly treated for years.'

"It must be remembered that this account, as well as the extract from Valentyn respecting the wild tribes of Ceram, is derived from the information of natives, who avowedly made parties for the express purpose of hunting them, and who are therefore in making them appear as much as possible in the light of wild beasts. Neither of these accounts alludes to the wild tribes as being woolly-headed, but this is a point on which no native is likely to give information, unless the question is expressly put to them. When on the coast of Borneo in 1843, we had a Papuan sailor on board the vessel, who formed one of

1 Dalton's "Notices," p. 49.-G. W. E. The term "Dyaks" should probably read "Kayans."-H. L. R. 
my boat's crew, and the peculiarity of his appearance was almost invariably a topic of conversation wherever we went, and if any of the natives we came in contact with had ever seen or heard of a people possessing similar peculiarities, the circumstance was nearly certain to be noticed.

"It is probable that information connected with the existence of this race in Borneo, which is of considerable ethnographical interest, may be found in Holland, among the documents containing the reports of government officers who have been despatched from time to time to make researches on the east coast of the island, as Dr. Roorda Van Eysinga, Professor of Oriental Languages and Geography to the Royal Military Academy of Holland, states, in his "Geography of Netherlands' India," that "In the inaccessible parts of the island " (Borneo) "Papuans yet reside in a savage state, bordering upon that of wild beasts." No authorities are quoted in the work, but as it is used as a class-book throughout the Netherlands, it cannot be supposed that the statement has been loosely made." (Earl's "Papuans," pp. 144-149.)

The reference by MM. Quatrefages and Hamy ("Crania Ethnica," pp. 194-196) to a comparison between the Negrito skull and that of the Andamese, induced me to turn to Mr. E. H. Man's work "On the Aboriginal Inhabitants of the Andaman Islands" (Lond., 1884), where on p. 119 there is a footnote reference to the kidnapping of the Andamanese by Malays, etc. It runs as follows :-

"Captain J. H. Miller, in a communication to the 'Nautical Magazine,' 1842, says : 'The islands in the west side of the Andamans are frequented during the fine season, from December to April, by a mixed and mongrel race of Malays, Chinese, and Burmese fishermen for bêche de mer and edible birds' nests, who are of very doubtful honesty, and it is necessary to take a few muskets and cutlasses, just to show them that you are prepared for mischief in case of need. These fellows are also 'fishers of men,' and to their evil deeds much of the hostility of the islanders may be attributed; they carry off children, for whom they find a ready market as slaves in the neighbouring countries. I have been told that formerly they were friendly, and assisted these fishermen, until a large party was invited on board a junk or prow (the Chinese got the blame of it), and after being intoxicated, were carried off and

1 “Ten zuiden van het koningrijk Borneo wonen de wilden volksstammen, Doesoems, K-a-jans en Maroets genaamd. In het outoegankelijk gedeelte van het eiland wonen nog Papoeaas in eenen staat van wildheid, dewelke aan dien der wilde dieren grenst." "Aardrijkbeschrijving van Nederlandsch Indie," p. 76.G. W. E. 
sold at Acheen : and the practice is still carried on by these fellows, who land and carry them off whenever they can catch them. The Andamanians have retaliated fearfully whenever any foreigner has fallen into their power, and who can blame them?"” ("Sailing Directions for the Principal Ports in the Bay of Bengal," by W. H. Rosser and J. F. Imray). On asking Mr. Man for further information, he kindly sent me the following extract: "Extract from an article entitled, 'One of the earliest accounts of two captive Andamanese,' edited from a paper by the late John Anderson, Esq., Secretary to Government Penang Civil Service, by his son, Captain T. C. Anderson, B.S. Corps, and published in a magazine called 'Indian Society,' May, 1867 : A Chinese junk, manned partly by Chinese and partly by Burmans, proceeded to the Andaman Islands, to collect bêche de mer, sea slugs (a great treat in China), and somewhat resembling a black snail, which the Chinese dry and eat, as well as edible birds' nests, which abound there. The crew of the junk, which was lying about two miles from the shore, observed eight or ten of the savages approaching the vessel, and wading through the water. Upon coming within a short distance of the vessel, they discharged several showers of arrows, which severely wounded four of the Chinese. . . . The Burmans gave immediate pursuit in their boat, and after much difficulty captured two of the savages. These were brought to Penang by the Chinese. . . . One of the savages was 4 feet 6 inches, and the other 4 feet 7 inches in height, and each weighed about 76 lbs. They had large paunches, and though they were so small, were in good condition.

"My father, in a work entitled 'Considerations relative to the Malayan Peninsula,' says in a paper on a tribe called 'Semangs,' 'There is little doubt that the degenerate inhabitants of the Andaman Islands in the Bay of Bengal are descended from the same parent stock as the Semangs. . . . Again, he says of a Semang whom he saw, "This man was at the time of his visit to Penang, when I saw him, about 30 years of age, 4 feet 9 inches in height. His hair was woolly and tufted, his colour a glossy jet black, his lips were thick, his nose flat, and belly very protuberant, resembling exactly two natives of the Andaman Islands who were brought to Prince of Wales' Islands (i.e., Penang) in the year 1819." "

At the same time he wrote me: "I feel sure, however, that the skulls found in Borneo, which differ so widely from those of Dyaks, can have nothing to do with the Andamanese, none of whom, so far as we know, were ever taken beyond Penang and Perak." But how can we tell to what distance these kidnapped islanders were taken? We have seen Chinese and Bur- 
mese pirates visited the Andamans. When the pirates were destroyed (190 killed or drowned and 31 taken to Sarawak), releasing 390 captives (140 by death only), "among the captives there were people from every part of the Eastern Archipelago, from Borneo, Celebes, Java, the smaller islands, and the "Malayan Peninsula" (Helms, 212). The wide range of the pirates, who brought their captives to the Sulu slave mart, is referred to by Dr. Guillemard (op. cit. p. 92). If Andanianese were carried to the Malay Peninsula, there is every probability of their having been carried further east, and hence possibly to Borneo. On asking M. Ernest Chantre, Director of the Muséum des Sciences Naturelles at Lyon, where the skull is deposited, for further information regarding its origin, he wrote me under date of 24th January, 1894: "All that I can tell you over and above what is mentioned in the 'Crania Ethnica' is, that it was obtained more than thirty years ago, as coming from Borneo, but we do not know under what circumstances it was got. In fact, I do not possess a single document. about it. I may, however, add that side by side with this engraved skull we possess another one equally small, not engraved, but blackened by smoke. It was purchased about ten years. ago from a natural history merchant of the city of Amsterdam, as coming from Borneo." Further requests for measurements. of this second skull failed to elicit any reply. The illustration of this engraved skull shows very characteristic Borneo tracery, and omitting the fact that we are not sure from what district of Borneo these engraved skulls are obtained, and also leaving apart the absence of mention by any one who has seen these engraved skulls hung up by the people who engraved them, we must conclude that this skull must have passed through the hands of Borneo people. But this by no means proves that the skull originally came from Borneo. So inuch for the artificial evidence. If the skull is so identical with that of Andamanese, as I understand MM. Quatrefages and Hamy appear to think-but which, as seen above, Dr. A. B. Meyer doubtsthen it may have been introduced. If, on the other hand, further independent examination should show it to be only generally similar, then it may possibly be indigenous. It may also be accepted that if the skull can be proved to have been brought from far inland, then we have better evidence that Negritoes exist or existed in Borneo.

In Professor Sir William Flower's "Catalogue, Royal College of Surgeons" (London, 1879), p. 125, he thus remarks on skull No. 745: "A cranium, said to be that of a Dyak. . . . It presents more Melanesian than Malay characters, and may be of Papuan origin, as Papuans are often taken to Borneo as 
slaves." It will be observed, Sir William Flower does not jump to the conclusion that Papuans are indigenous to Borneo.

In this enquiry no reference is made to the presence of the Negrito in prehistoric times. If, as now appears to be generally accepted, the Negro family, like the rest of mankind, had its origin in the Indo-African continent (Keane's "Ethnology," pp. 229, 242), it may be probable that Negritoes once existed in Borneo. On the other hand, Borneo is comparatively new. It consisted originally of a few islands, which were later on joined together, and ultimately took on a shape very similar to that of Celebes now, the larger portion of the present form of Borneo being recent geologically, tertiary and post tertiary (see Posewitz). ${ }^{1}$ As one island it probably did not exist at the time of the final disappearance of the Indo-African continent. The only stone implement found so far is the neolithic one illustrated in the J.A.I., i, P.E.S., p. xxxix, found by Mr. A. Hart Everett, but others may yet be found. The evidence of an ancient occupation of the island is still wanting, and with it necessarily any trace of Negrito occupation. As for the present day the existence of the Negrito in Borneo has yet to be proved.

Discovery of Evidences of the Palazolithic Stone Acte in Somaliland (Tropical Africa). By H. W. Seton-Karr.

\section{[WIth PLATES XIX-XXI.]}

LAST September at the British Association Meeting at Ipswich, I exhibited some stone implements which I had discovered during my third and fourth journevs in Somaliland, and I stated that this was the first evidence of the stone age found in tropical Africa. During my third expedition, I met a gentleman in the interior of Somaliland, a merchant and banker residing at Aden, to whom I explained the nature of my discoveries, and gave a few specimens, asking him not to mention the subject to anyone in Aden on his return until I had more thoroughly searched the district for specimens. He appears, however, to have told the French at Jibuti, for in the last quarter's "L'Anthropologie" there is an article on the subject mentioning him as an intelligent traveller, and figuring some implements of a much ruder type than the majority of those I have since then discovered. The specimens first exhibited indicated, by the weathering of them, very great antiquity, but Sir John Evans was doubtful whether they might belong to the early neolithic period or to the palæolithic, as the

1 “Borneo : Its Geology and Mineral Resources," Lond. 1892, pp. 259-260. 